підголосків до пісні; добирання пропущеного в мелодії пісні звука; закінчення початої вчителем мелодії; мелодизація віршованих текстів, лічилок, дражнилок, загадок, забавлянок; складання власних музичних композицій, наприклад, на теми «Голоси птахів», «Космічна музика», «Осінь», «Ураган», «Сумний настрій», «Весела музика», «Діалог двох бубнів», «Діалог двох дзвіночків» тощо.

Застосування подібних комунікативних музичних вправ, у яких беруть участь усі учні і вчитель, забезпечує внутрішній психологічний комфорт на уроці, добрий настрій, за якого працюється більш цікаво і більш результативно. Очевидна дидактична спрямованість таких уроків: поглиблюються музичні знання та музикальні вміння учнів; думка дитини працює активно; розвивається образноасоціативне, творче мислення; формуються навички самостійної постановки i розв'язання творчих завдань.

Цілісний розвиток творчої особистості вимагає застосування різних форм музичнотворчої діяльності в доступних для молодшого школяра видах, а також організації змістовного дозвілля дітей, спілкування, накопичення досвіду. Оскільки молодший учень особливо сенситивний до педагогічного впливу, виховання творчо активної особистості є важливим на стадії початкового навчання, коли закладається фундамент становлення, подальшого розвитку, збагачення й удосконалення особистості учня.

\title{
Література
}

1. Гродзенская Н. Л. Школьники слушают музыку / Н. Л. Гродзенская. - М. : Просвещение, 1969. - 76 с. 2. Куненко Л. О. Естетичні та мистецькі засади формування духовної культури особистості /Л. О. Куненко // Науковий часопис НПУ імені М. П. Драгоманова. Серія 14. Теорія і методика мистецької освіти : зб. наук. праць. - К. : НПУ імені М. П. Драгоманова, 2011. - Вип. 12 (17). - С. 107-111. 3. Куненко Л. О. Науково-педагогічні засади особистісно-зорієнтованих технологій музичного навчання молодших школярів / Л. О. Куненко // Педагогіка вищої і середньої школи: зб. наук. праць. - К-Р. : СПД Щербенок С. Г., 2011. - С. 486-492. 4. Русова С. Ф. Дошкільне виховання / С. Ф. Русова. - Катеринослав, 1918. - С. 9, 15.

\section{ДІАЛОГОВА СУТНІСТЬ ОСОБИСТІСНО ЗОРІЕНТОВАНОЇ ПАРАДИГМИ ОСВІТИ}

Зуєнко Н. О. Діалогова сутність особистісно зорієнтованої парадигми освіти.

Особистісно зорієнтована парадигма освіти аналізується в контексті діалогової природи суб'єкт-суб'єктної взаємодії учасників освітнього процесу, що дозволяє поглибити розуміння шляхів реалізації в навчально-виховному процесі ВНЗ особистісно зорієнтованих освітніх технологій. Розглядається емоційно-естетичний аспект педагогічного діалогу.

Ключові слова: парадигма освіти, особистісно зорієнтоване навчання, педагогічний діалог, освітня технологія.

Зуенко Н. О. Диалоговая сущность личностно ориентированной парадигмы образования.

Личностно ориентированная парадигма образования анализируется в контексте диалоговой природы субъект-субъектного взаимодействия участников образовательного процесса, что позволяет углубить понимание путей реализации в учебно-воспитательном процессе ВНЗ личностно ориентированных 
образовательных технологий. Рассматривается эмоционально-эстетический аспект педагогического диалога.

Ключевые слова: парадигма образования, личностно-ориентированное обучение, педагогический диалог, технология образования.

Zuenko N. O. Dialog essence of the personality oriented paradigm of education.

The personality oriented paradigm of education is analyzed in the context of dialog nature of subject-subject interaction of the participants of educational process, that allows to deepen the understanding of the ways of realization in the studying and upbringing process of higher educational establishments the personality oriented educational technologies. The aesthetically emotional aspect of pedagogical dialog is examined.

Key words: paradigm of education, student-pointed training, pedagogical dialogue, education technology.

Як зазначається в освітніх державних документах, зараз існує нагальна необхідність створення умов для розвитку і самореалізації кожної особистості, виховання в неї комунікативної культури як необхідної умови інтеграції молодої людини в соціальні, природні та виробничі процеси. Відтак, комунікативна культура та їі головний прояв - діалогічна діяльність завжди були в центрі уваги науковців.

Різні аспекти людських зв'язків у контексті комунікативної культури й діалогу аналізувалися у творах таких класиків філософії, як Дж. Локк, Т. Гоббс, Г. В. Ф. Гегель, К. Маркс, Е. Дюркгейм, М. Вебер, М. Бердяєв, П. Сорокін та ін. У дослідженнях $з$ педагогіки і психології зростає увага науковців до спілкування, соціальної взаємодії, діалогових форм освітнього процесу як важливих умов самореалізації й досягнення життєвих цілей людини у взаєминах 3 оточенням (Т. Вільчинська, А. Гелен, М. Гінзбург, О. Гойхман, М. Коул, К. Левітан, Б. Ломов, В. Мерлін, М. Молоканов, Ч. Каррасс та ін.). Вагомий внесок у поглиблення розуміння комунікативної культури й діалогу зробили такі науковці, як Б. Ананьєв, М. Бахтін, В. С. Біблер, Л. Божович, І. Василенко, Л. Виготський, О. Добрович, О. Петровський та ін., які досліджували культуру міжособистісних відносин і засоби гуманізації людського спілкування через діалогові форми людської взаємодії.

Відповідно, актуальним постає поглиблення розуміння діалогу як соціального та особистісного феномену в контексті його глибинної сутності та зв'язків із навчальним процесом. Метою статmі є дослідження діалогової суті особистісно орієнтованої парадигми освіти, що дозволить поглибити розуміння шляхів іiі реалізації в навчально-виховному процесі ВНЗ. Теорія особистісно зорієнтованої освіти визначає своїм завданням рефлексувати деякі закономірності цього процесу.

Як свідчить аналіз наукових джерел, діалог як універсальна природна форма людського спілкування $є$ сукупністю реплік, пов'язаних відносинами «стимул-реакція», взаємообумовлених i взаємопов'язаних в структурному, семантичному і функціонально-прагматичному планах, які змінюють одна одну та утворюють цілісну комунікативну одиницю акту спілкування [5]. У їі межах учасники діалогу складають суб'єкт-суб'єктну, діалектичну єдність, всі елементи якої виявляють синергетичну цілісність, оскільки ролі діалогічної взаємодії не закріплені за окремим комунікантами, подібно до ролей акторів в п’єсі [14, с. 4-8]. Тому тут утворюється діалоговий ланцюжок, відбувається так званий «колооберт мови» [10, с. 4-18]. В аспекті педагогіки діалог може 
розумітися як універсальна характеристика педагогічної ситуації, що зумовлює особистісний розвиток індивіда.

Діалогічність $є$ універсальною характеристикою людської взаємодії, оскільки вона передбачає міжетнічний, міжчасовий, міжісторичний, міжконфесійний діалоги. У цьому аспекті для сучасної освіти найбільш актуальним $\epsilon$ полікультурний діалог, оскільки освіта i виховання мають спиратися як на загальнолюдські, так і на прогресивно-національні принципи, зважати на специфіку і досвід етнокультури [7].

Особистісно розвивальий потенціал діалогу пов'язаний 3 діалогічною природою особистості, яка існує в постійному внутрішньому діалозі з самою собою i в ній спостерігається своєрідний рух від свідомості до мислення і навпаки. В. С. Біблер розуміє під мисленням свідомість, яка одержує зовнішнє оформлення, екстеріоризується, перебігаючи із внутрішнього до зовнішнього плану психічної діяльності індивіда: обговорюючи внутрішній досвід із самою собою, особистість оформляє його в розумових конструкціях, текстах, вчинках і висловах [4].

Слід сказати, що діалог як прийом навчання, як найбільш сприятлива форма відносин суб'єктів навчального процесу відома 3 давніх часів. Діалог у цьому ракурсі може розглядатися як специфічне соціокультурне середовище, що створює сприятливі умови для сприйняття особистістю нового досвіду, ревізії колишніх сенсів тощо. Тому можна говорити про так званий гуманітарний компонент освіти, який виявляє обов'язкову особистісну співучасть, унаслідок чого навчальний матеріал не може бути сприйнятий студентом інакше, ніж через діалог 3 іншими учасниками освітнього процесу або з самим собою. Отже, навчальний процес $\epsilon$ послідовністю «діалогів», що органічно розвиваються та складають єдиний, безперервний, незавершений діалог [3].

Загалом діалог - це підтвердження для особистості їі цінності i, як наслідок, народження бажання стати ще кращою. Отже, предмет діалогу завжди лежить в контексті особистісних цілей, інтересів, сенсів співбесідників [8, с. 77-80]. Саме тому діалог є завжди надпредметною сутністю, він розширює межі пізнаваного за рахунок обміну не тільки інформацією, але й оцінками, сенсами, гіпотезами. Діалог у навчальній сфері при иьому стимулює творчу діяльність, оскільки однією 3 характеристик творчої особистості є її здатність продукувати гіпотези, оперувати віртуальними, потенційно-можливими категоріями.

3 огляду на викладене вище можна зробити висновок, що потреба в діалозі духовна потреба людини i, як усі потреби такого роду, вона $\epsilon$ «ненасичуваною», тобто не може бути повністю реалізованою. Звідси принципова незавершеність діалогу, його синергетично-рекурсивна сутність [3].

Іншою найважливішою характеристикою діалогу $\epsilon$ те, що його завдання відокремити «особисте» від об'єктивних достоїнств або недоліків обговорюваного предмета, диференціювати значення і сенс. Тому рефлексія позиції учасників діалогу, ii логіко-вербальний виклад органічно поєднується 3 когнітивним, дослідницьким ставленням до проблеми. Ця подвійність діалогу робить його універсальною характеристикою навчально-розвивальних освітніх технологій.

Залучення студента до діалогу й означає створення особистісно розвивальної педагогічної ситуації. Відтак, інтуїтивно пошук шляхів входження в діалог 3 вихованцем здійснює кожен педагог, у якій би сфері він не працював.

Важливо, що у психології діалогу можливі дві протилежні позиції: гіпертрофія можливостей втручання педагога у внутрішні конструктивні процеси особистості і 
залишення вихованця наодинці з його проблемами. Обидві дослідники вважають прихованими формами насильства над вихованцем [12].

Найважливішою характеристикою особистісно зорієнтованих технологій навчання $є$ готовність до діалогу його учасників як один з універсальних показників сформованості індивіда як особистості. Ця готовність передбачає спрямованість на пошук сенсу цінностей, що вивчаються, можливість суб'єктивно сприймати матеріал, визначати «межі інших думок» [3].

Аналіз різних особистісно зорієнтованих технологій показує, що учасники освітнього процесу беруть участь у діалозі 3 різним ступенем активності і особистісного прийняття ситуації. У дослідженні С. Бєлової диференційовані, наприклад, три групи вихованців: ті, що формально беруть участь у діалозі (імітують свою участь у ньому); ті, що навчаються 3 домінуючим прагненням захистити власну позицію i, у зв'язку з цим, вельми критично налаштовані на різні «вербально-знакові» думки та переконання; група тих, які дійсно поводяться «діалогічно», тобто прагнуть збагатити, а то й переглянути свою позицію, подивившись на себе з боку, тобто вийшовши за межі звичної життєвої ситуації [3].

Отже, діалогова природа навчальної взаємодії сприяє розвитку у його учасників умінь контролювати свої навчальні операції, що розвиває самоконтрольний потенціал особистості. Це досягається за допомогою необхідності прийняти думку співбесідників усім учасникам діалогу, абстрагуватися i дистанціюватися від своєї особистісної позиції, дивитися на себе і ситуацію діалогу з боку. Відтак, у процесі діалогу людина навчається контролювати свою поведінку та виробляє активну життєву позицію, розвиває вміння брати відповідальність за свої вчинки, оскільки, як засвідчують психолого-педагогічні дослідження, людина може брати відповідальність тільки за те, що може контролювати [15].

Діалог також постає своєрідною технологією засвоєння емоційно-ціннісного досвіду, досвіду діяльності з пошуку сенсу життя під час вивчення гуманітарних предметів (точніше, гуманітарного компоненту будь-яких предметів) [8, с. 77-80].

Проблеми, що вимагають діалогічного способу дослідження, засновані на пошуку духовного співвідношення людини зі світом і виникають як своєрідний перетин декількох площин світосприймання - філософського, етичного, естетичного, побутового. Початковим станом проблеми тут постає особистість. При цьому діалог передбачає запитання, завдання, проблеми, розраховані не стільки на інтерес до них, скільки на інтерес до особистості, якій вони адресовані. Головна характеристика учасника діалогу - готовність до пошуку сенсу цінностей і колізій, 3 якими він зустрівся в діалогічній ситуації [3].

Психолого-педагогічні дослідження засвідчили, що студенти не відразу опановують досвід діалогу. На початковому етапі застосовуються імітація, своєрідна гра в діалог: розподіляються ролі «нігіліста», «критика», «опонента», «захисника». Особистісно-смисловий діалог постає наслідком своєрідного співрозвитку викладача i студента, зближення їх цінностей, усвідомлення їх особистісного (не функціонального) рівноправ'я, зростання взаємної довіри. За цих умов презентація викладачем своїх сенсів $\epsilon$ тонким інструментом дії на особистісний досвід студентів [3].

Іншим важливим моментом діалогічності навчального процесу $є$ емочійноестетичний аспект діалогічної ситуації, оскільки саме в затвердженні духовноособистісного потенціалу індивіда і полягає функція естетичного (М. М. Бахтін, T. І. Чечет) [2, с. 13]. 
До естетичних аспектів особистісно зорієнтованої педагогічної діяльності відносять орієнтацію на цілісну особистість освітнього процесу; стимулювання суб'єктності, Я-позиції студента як рівноправного партнера; створення ситуації діалогу, творчості, творчої гри, що спонукають студента до пошуку сенсу пізнання й інших життєвих цінностей, до сприйняття культури, що вивчається, в іï естетичній цілісності. Саме тут виявляється пріоритет особистісного, суб'єктного досвіду над предметно-знаннєвими компонентами освіти, синтез образного і понятійного, емоційного і логічного, практико-орієнтованого й естетичного у викладі матеріалу. Це досягається через застосування специфічних освітніх технологій - контекстних, діалогічних, ігрових, таких, що забезпечують особистісний рівень засвоєння змісту освіти, що вивчається, виявляючи особистісно-смисловий рівень спілкування суб'єктів освітнього процесу.

Суб'єкт-суб'єктне спілкування не замінює всього різноманіття функцій освітнього процесу, але воно відіграє роль специфічного механізму формування особистісного досвіду. Провідною характеристикою ситуації такого спілкування $\epsilon$ сприйняття партнера в його самозначущості, тобто не як інструменту, засобу для досягнення чогось, а як мету спілкування.

Відтак, завдяки своїй емоційно-естетичній природі особистісно зорієнтована педагогічна ситуація виконує важливі функції в освітньому процесі. Вона мотивує прийняття й обгрунтування діяльності та певного напрямку поведінки; створює емоційно-енергетичне підкріплення активності й умови для самопрезентації, відкриття особистістю власних сенсів. Особистість уводить етичні, духовноестетичні критерії в оцінку і регуляцію своєї життєдіяльності; автономна життєдіяльність і освітній процес тут інтегруються в цілісність: в особистості ніщо не «утворюється» без їі власних зусиль; усвідомлюючи себе носієм самостійності і свободи, особистість починає цінувати ці властивості і в інших людях, що й підсилює в ній позицію толерантності і діалогічності [2; 8; 13].

Емоційно-естетичний аспект педагогічного діалогу не можна віднести цілком лише до зовнішньої форми навчального заняття. Він органічно пов'язаний із змістом, проте виходить за межі логічної наочності. Природне звернення до особистісної сфери учасників діалогу відбувається тоді, коли ними усвідомлюється обмеженість можливостей адекватного засвоєння матеріалу під час його лише логіко-поняттєвої інтерпретації, і виникає необхідність в спеціальних естетичних діях - драматизації, введенні художніх текстів, емоційно-естетичному самовираженні учасників навчального процесу через креативність, художність, експресивність.

Отже, у процесі спілкування виявляється емоційний аспект, зумовлений статусно-рольовою диференціацією учасників освітнього процесу, специфікою умов роботи, рівнем складності завдання, індивідуальною чутливістю, рівнем домагань, ставленням до завдання i до партнера. I якщо в центрі уваги у навчальному процесі знаходиться особистість, то сама навчальна діяльність має будуватися так, щоб будь-яке ставлення до будь-якого об'єкта реалізувалося через ставлення до іншої людини. Відтак, у фокусі педагогічного процесу опиняється не ставлення до об'єкта, а ставлення людей один до одного 3 приводу об'єкта їх діяльності [11]. Саме в контексті такої емоційно-естетичної координації В. Рубцов ставить запитання: у чому специфіка того предмета, на який спрямована дія? У чому саме полягає необхідність спільності для досягнення цього предмета? Як здійснюється пошук цього предмета в сумісній дії? У результаті дослідження цей науковець доводить, що суть спільності полягає в розподілі дій і операцій, обміні 
діями, а також взаєморозумінні, комунікації, плануванні і рефлексії. Під час спільної діяльності рефлексуюча увага студентів звертається саме на дію, а не тільки на те, «що вийде» в результаті цієї дії [9].

Важливим при цьому $є$ те, що діалогічна форма навчання $є$ необхідною умовою реалізації його групових форм, що дозволяють вивільняти творчий потенціал особистості, який може розглядатися як їі інтеграційна якість, що забезпечує ефективну взаємодію з іншими людьми і продуктивність діяльності.

Загалом можна говорити про різні форми групової роботи на уроці, які реалізують такі методи, як метод діалогічних взаємодій, колективно-розподілену діяльність, групові заняття, особистісно-рольову організацію, дискусії, семінари, співбесіди. Групова робота дає досвід взаємодії в незнайомих ситуаціях, що вимагають вибору поведінки і перенесення знань, умінь, навичок. Особистість, що володіє таким досвідом, здатна діяти активно, самостійно, творчо, збагачувати своє життя і життя інших людей $[1 ; 2 ; 4]$.

Діалогові форми колективної навчальної діяльності $\epsilon$ передумовами виникнення особистісно зорієнтованої ситуації в навчанні. Як ознаки колективної навчальної діяльності дослідники називають розподіл частин навчального завдання відповідно до індивідуальних можливостей вихованців за наявності спільності мети, вибору партнерів спілкування, усвідомлення своєї ролі в групі тощо. Організовуючи таку роботу, викладач має забезпечити необхідний рівень засвоєння матеріалу кожним учасником групової роботи. Викладач стежить також за тим, щоб вирішення суб'єктами поведінкових i міжособистісних завдань не руйнувало когнітивну діяльність, специфічну для дисципліни, що вивчається.

Отже, діалогова природа особистісно зорієнтованої освітньої парадигми виявляє такі ресурси навчального діалогу, як смислова спрямованість навчального процесу, реалізація його емоційно-когнітивних механізмів, творчість i надситуатівность, здатність до формування в особистості відповідальності, вольових механізмів самоконтролю, умінь розв'язувати проблеми. Ці висновки вимагають подальших поглиблених досліджень щодо їх практичної реалізації.

\section{Література}

1. Асмолов А. Г. Культурно-историческая технология и конструирование миров / А. Г. Асмолов. - М. : Наука, 1996. - 258 с. 2. Бахтин М. М. Эстетика словесного творчества / М. М. Бахтин. - М. : Знание, 1979. - 423 с. З. Белова С. В. Функции учебного диалога в усвоении ценностно-смыслового содержания гуманитарных предметов: автореф. 196ис.. на соискание ученой степени канд. пед. наук / С. В. Белова. - Волгоград, 1995. - 20 с. 4. Библер В. С. Нравственность, культура, современность: Философские рассуждения о жизненных проблемах / В. С. Библер. - M. : Политиздат, 1988. - 412 с. 5. Бузаров В. В. Круговорот диалогической речи, или взаимодействие грамматики говорящего и грамматики слушающего / В. В. Бузаров. - Ставрополь: Изд-во СГУ, 2001. - 168 с. 6. Глебов А. А. Деловое общение старшеклассников на уроке / А. А. Глебов, А. А. Донсков // Обновление и развитие современного урока. - Волгоград, 1992. С. 42-47. 7. Гогоберидзе Г. М. Диалог культур в системе литературного образования / Г. М. Гогоберидзе. - М. : Наука, 2003. - 183 с. 8. Знаменская С. В. Педагогические условия формирования коммуникативной культуры студентов в процессе профессиональной подготовки в вузе: дис. ... канд. пед. наук: 13. 00. 08 «Теория и методика профессионального образования»/ Знаменская Стояна Васильевна. Ставрополь, 2004. - 213 с. 9. Рубцов В. В. Совместная деятельность как проблема генетической психологии / В. В. Рубцов // Психологический журнал. - 1989. - 
Т. 10. - № 3. - С. 8-16. 10. Серебренников Б. А. К проблеме сущности языка / Б. А. Серебренников // Общее языкознание / [под ред. Б.А. Серебренникова]. - М. : Наука, 1970. - С. 4-18. 11. Философско-психологические проблемы развития образования / [под ред. В. В. Давыдова]. - М., 1981. -145 с. 12. Фролова Т. Педагогический смысл помощи и поддержки / Т. Фролова, Н. Иванова // Воспитание и педагогическая поддержка детей в образовании / [под ред. О. С. Газмана]. - М., 1996. - С. 34. 13. Чечет Т. И. Подготовка будущих учителей к созданию эмоционально-эстетических ситуаций в процессе личностно ориентированного обучения: автореф. ... канд. пед. наук. - Волгоград, 1997. - 21 с. 14. Шубин Э. П. Языковая коммуникация и обучение иностранным языкам/ Э. П. Шубин. - : Просвещение, 1972. - 56 c. 15. Rotter L. B. Generalized expectancies for internal versus external of reinforcement / L. B. Rotter // Psychological monographs. - 1966. - Vol. 80. - P. 1-28.

\section{Елена Карманова}

\section{ФОРМИРОВАНИЕ ПРОФЕССИОНАЛЬНОЙ КОММУНИКАТИВНОЙ КОМПЕТЕНЦИИ В ГРУППАХ С РАЗЛИЧНЫМ УРОВНЕМ ПОДГОТОВКИ}

Карманова Е. И. Формирование профессиональной коммуникативной компетенции в группах с различным уровнем подготовки.

Рассмотрены некоторые аспекты и методы формирования профессионально ориентированной коммуникативной компетенции студентов с различным уровнем подготовки, использование интернет-технологий и роль преподавателя в этом процессе.

Ключевые слова: профессиональная коммуникативная компетенция, группы разноуровневой подготовки, интернет, интерактивность, подходы к обучению.

Карманова О. І. Формування професійної комунікативної компетенції у групах 3 різним рівнем підготовки.

Розглянуто певні аспекти й методи формування професійної комунікативної компетенції студентів 3 різним рівнем підготовки, використання інтернеттехнологій та роль викладача в цьому процесі.

Ключові слова: професійна комунікативна компетенція, групи різнорівневої підготовки, інтернет, інтерактивність, підходи до навчання.

Karmanova O. I. Formation of Professional Communicative Competence in Groups with Different Levels of Training.

Some approaches and aspects of forming the professional communicative competence, the use of the Internet are considered; the role of a teacher in this learning environment is defined.

Key words: professional communicative competence, mixed abilities class, Internet, interactive activities, teaching approaches.

Общая гуманистическая направленность современного образования заключается во всестороннем развитии личности, ее общих способностей и задатков, формировании всех жизненно важных компетенций: социальных, коммуникативных, информационных, технологических, профессиональных и других. Коммуникативно-ориентированный и профессионально направленный 